\title{
Negotiating Women's Rights: Activism, Class, and Modernization in Pahlavi Iran
}

Mana Kia

$A$ great deal has been written on the subject of women in twentieth-century Iran, from a variety of approaches and perspectives. Many of these works treat the issue of women's rights either referentially or directly. These studies generally provide an account of women's rights in prerevolutionary Iran as background, often contrasting the lack of activism in the 1960 os and 197 os with women's mass participation in the Anti-Shah Revolution ${ }^{1}$ or with the burgeoning of activism after the establishment of the Islamic Republic. ${ }^{2}$ Studies focusing on the broader historical frame of the twentieth century often have little to say about the two decades preceding the Anti-Shah Revolution. ${ }^{3}$ In both types of studies, women's rights are often thought of as direct results of state modernization policies, bestowed from above as royal grants, precluding any discussion of activism.

Paradoxically, scholars who write in opposition to the Pahlavi state, as well as those who write supportively of it, share this view. Royalist narratives uncritically dismiss or omit women's activism when it occurs outside the purview of state activities. ${ }^{4}$ The notion of women's rights as royal grants is premised on a concept of the state as the institutional manifestation of the monarch, with all state laws and policies occurring through the shah's agency. The shah is seen to act for the good of the people, helping the enlightened realize their goals and helping those too traditional to know what is best for them, sometimes with a firm hand. ${ }^{5}$ Thus women working within the state are acknowledged, but only as instruments of state policy.

This article is drawn from my master's thesis, which benefited from the comments of many insightful readers. My thanks to Andrew Davison, Mehdi Khorrami, Farbod Mirfakhrai, Afsaneh Najmabadi, Andrew Ralston, and A. Seth Young. Any errors, of course, are mine.

1. I refer to the Iranian revolution of $1978-79$ as Anti-Shah because the common goal of mass participation was dethroning the shah rather than establishing an Islamic government.

2. See, for example, Azar Tabari and Nahid Yeganeh, eds., In the Shadow of Islam: The Women's Movement in Iran (London: Zed, 1982); Guity Nashat, ed., Women and Revolution in Iran (Boulder, CO: Westview, 1983); Haideh Moghissi, Populism and Feminism in Iran: Women's Struggle in a Male-Defined Revolutionary Movement (New York: St. Martin's, 1994).
3. See, for example, Eliz Sanasarian, The Women's Rights Movement in Iran: Mutiny, Appeasement, and Repression from 1900 to Khomeini (New York: Praeger, 1982); Parvin Paidar, Women and the Political Process in Twentieth-Century Iran (Cambridge: Cambridge University Press, 1995); Janet Afary, "Steering between Scylla and Charybdis: Shifting Gender Roles in Twentieth Century Iran," NWSA Journal 8 (1996): 28-49.

4. See, for example, Ashraf Pahlavi, Faces in a Mirror: Memoirs from Exile (Englewood Cliffs, NJ: Prentice-Hall, 1980).

5. See, for example, Mohammad Reza Pahlavi, Answer to History, trans. Michael Joseph (New York: Stein and Day, 1980); Badr ol-Moluk Bamdad, From Darkness into Light: Women's Emancipation in Iran, trans. F. R. C. Bagley (Hicksville, NY: Exposition, 1977); George Lenczowski, "Political Process and Institutions in Iran: The Second Pahlavi Kingship," in Iran under the Pahlavis, ed. George Lenczowski (Stanford, CA: Hoover Institution Press, 1978), 433-75.

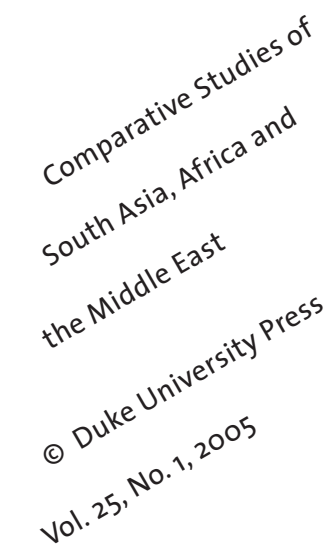




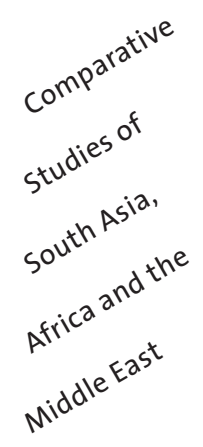

In response to royalist narratives that either discredit or appropriate activism outside the state, oppositional scholarship ends up uncritically dismissing or omitting women's activism when it cooperates with or works through the state. A line is drawn between institutionally independent activism and activism through the state, and the former is lauded at the expense of the latter. While this can constitute a means of resistance to royalist narratives, the result is that oppositional scholarship unwittingly participates in the same erasure of agency of women's rights activists, except this erasure is directed toward activists working within the state.

Both writings assume the total dominance, absolute power, and uniformity of the Pahlavi state, leaving little room for locating resistance and agency from within it. This notion of the Pahlavi state is premised on a direct and unquestioned correlation of institutional independence with ideological independence. Such a linkage is problematic, given the porous nature of ideological domination and the flimsy protection provided by institutional separation. Institutional independence from the state creates a difference of position, which does not necessarily afford ideological immunity. To achieve its goals, any organization or movement that does not seek to replace the state must engage with the state institutionally and ideologically. This is especially true in a nondemocratic political structure.

But if the state is a manifestation of the shah and has a monopoly on power, then how do we explain legal rights that women gained under a misogynist shah? ${ }^{6}$ How do we explain the care with which state modernization policies were discursively framed in accordance with Islamic precepts? The state's modernization discourse and policy occurred in a field of discursive forces, not a vacuum, and these dialogues of relation created boundaries and limits on the power and language of each discourse.
While women's rights activism may have become circumscribed by state institutional control, the state was also required to absorb activists' demands. This poses the question of how to understand feminism within a context where political restrictions do not necessarily allow for formal women's organizations separate from the state. "The difficulty of discussing ThirdWorld feminism arises in the first instance as a difficulty of identifying the concretions and forms of effectivity in the Third World that can be grasped as feminist." " Instead of dismissing women's organizations once they engage with the state, I examine the results of that association. I focus on understanding women's rights in the Pahlavi era as the result of a power negotiation between different forces, creating a more porous view of the state. Specifically, I ask how the state's discourses of modernization and development interacted with, framed, and affected the feminist discourse of women's rights. ${ }^{8}$ In what way did women's rights activists who chose to work within the state use modernization discourse to achieve their goals?

The evolution of women's organizations and their activities culminating in the creation of the Women's Organization of Iran (WOI) and the narratives of various state-affiliated women's rights activists are my primary focal points. I suggest that feminist activism undertaken within state institutions cannot be dismissed as a direct extension of state policies. This activism needs to be examined in a way that allows us to locate agency and resistance to state dominance, as well as the results of such dominance. Analyzing the question of women's rights as a complex relationship defined by power negotiation is critical to reassessing the implications of feminist activism within a modernizing state.

\section{Institutional Autonomy = Ideological Independence?}

In oppositional scholarship, a major assumption in evaluations of women's rights activism
6. For the shah's views on women, see Oriana Fallaci, "Muhammad Reza Pahlavi," in Interview with History, trans. John Shepley (New York: Liveright, 1976), 264-72; and R. K. Karanjia, The Mind of a Monarch (London: Allen, 1977), 178-87.
7. Geraldine Heng, “'A Great Way to Fly': Nationalism, the State, and the Varieties of Third-World Feminism," in Feminist Genealogies, Colonial Legacies, Democratic Futures, ed. M. Jaqui Alexander and Chandra Talpade Mohanty (New York: Routledge, 1997), 30.
8. Development refers to state policies geared toward developing industrial capitalism in Iran. Modernization refers to the state's social policies designed to create citizens and include them in this process of capitalist development. 
in Pahlavi Iran is that only activities and organizations independent of the state are considered feminist or as constituting a women's movement. ${ }^{9}$ A notion of autonomy is the analytic pivot of this assumption. Political critiques of the Pahlavi state often reflect a desire for democratic rights and institutions. Many of these critiques point to nearly nonexistent avenues for feminist activism other than through the state or through guerrilla movements. ${ }^{10}$ One symptom of this critique is the inclusion into history of the activism that the state dismisses, the activism occurring outside the state. These analyses adopt rigid notions of what constitutes the boundaries of the state. Thus agency is recognized according to a polarized dichotomy of domains: inside and outside the state. Although this is not the goal of the critique, the process of writing activists outside the state back into history often results in activists within the state being concomitantly stripped of agency. The following literature review is not meant to be comprehensive or to claim that all scholarship on women's rights in Iran falls prey to these dangers. My intention is to provide a sketch of a general tendency in order to contextualize the conceptual concerns explored in this article. A notion of autonomy creates a distinguishing line between activists as agents and activists as government tools. Ignored is the possibility that "the response of a Third-World feminism under threat must be, and has sometimes been, to assume the nationalist mantle itself."11 I do not dispute the significance of institutional freedom; however, I would like to point out some dangers of this kind of analysis.

Eliz Sanasarian's The Women's Rights Movement in Iran: Mutiny, Appeasement, and Repression from I 900 to Khomeini is one of the first book-length works written on women's rights in Iran and serves as a secondary source for many scholars. The work spans women's rights ac229 tivism in the twentieth century up through the establishment of the Islamic Republic. Sanasarian's primary concern is identifying activism as a social movement according to characterizations of social movements theoretically formulated in the context of an idealized North America. ${ }^{12}$ Her analysis traces the women's movement through a unilinear trajectory of origin, rise, decline, and extinction. In her optic, the Constitutional Revolution of 1905 marks the origins of women's activism. The rise of this activism into a movement ends with the dismantling of the Patriotic Women's League in 1932. Sanasarian makes the startling assertion that "the disbanding of the last independent women's organization in 1932 marked the end of the women's movement in Iran."13 This assertion is partly linked to her theoretical framework, which contends that a social movement must be in opposition to an official establishment. ${ }^{14}$ There is a direct and uncritical correlation here between a movement and institutional independence. Can we really assume that the same activists Sanasarian vests with agency when outside the state lost that agency simply on account of entering the state? At the very least, this possibility merits exploration rather than dismissal.

Many scholars view the central government as weak during 1941-53 and concentrate on the emergence of numerous political parties and organizations. While it is generally acknowledged that this context allowed for the "independent" activity of many women's rights activists, scholars note the failure of nationalist political parties to produce any significant changes in the legal position of women. This failure is attributed to the auxiliary position of many women's organizations in relation to male-run political parties.
9. For a notable exception to the tendency to strip activists of agency once they work through the state, see Afsaneh Najmabadi, "(Un)Veiling Feminism," Social Text, no. 18 (2000): 29-45.

10. Sima Bahar acknowledges women's rights activists who "had been struggling for over fifty years." However, this definition of activism does not seem to include activists working within the state, since the 1953 coup d'état resulted in an end "to the political activities of women," only to be rekindled "with the beginning of the Siahkal Movement." She dismisses the activities of the High Council of Women, claiming that it was "fully controlled by the regime." Thus the only activists with any legitimacy or agency in her analysis are women involved in the guerrilla movement ("A Historical Background to the Women's Movement in Iran," in Women of Iran: The Conflict with Fundamentalist Islam, ed. Farah Azari [London: Ithaca, 1983], 181-82).

11. Heng, "Great Way to Fly," 34.
12. Sanasarian, Women's Rights Movement in Iran, 4. This context seems to presuppose a political atmosphere that allows for civil society independent of the state.

13. Ibid., 28.

14. For instance, she states that this established opponent "could be a government, a specific group in society, or an institution," but that social movements "work against the general stream of things" (Sanasarian, Women's Rights Movement in Iran, 29). 


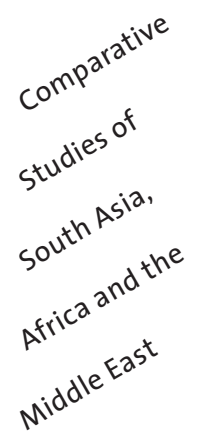

Janet Afary's discussion of the 1941-53 period is characterized by an understanding of women's activism as institutionally subjugated to the broader political agendas of political parties, which privileged nationalist ideas over what were seen as special interests, such as female suffrage. This understanding of the ideological subordination of women's rights to nationalist issues makes the same uncritical correlation between ideological subservience and institutional subservience as does Sanasarian. "Even one of the most outspoken women's organizations," because it was a separate, auxiliary wing of a larger political party with nationalist goals, "placed greater priority on nationalist and general political demands than on the issue of women's rights." ${ }^{15}$ Again we are presented with the idea of a reified masculine political force, this time a political party instead of a king, impervious to any kind of influence from below or within. According to Afary, the agency of outspoken activists is replaced by the agency of this dominating masculine force. We are left with little room to understand how the negotiation of power in this period resulted in almost no legal changes for women.

Scholars generally describe the post-1953 period as a time when the monarchy asserted its hegemony over state power by eradicating all opposition. Most women's rights activism was seen as centered on the campaign to gain the right to vote and run for office. After this right was gained and the WOI formed several years later, the Family Protection Law, commonly viewed as a product of the state, was passed. The process by which these laws came into being, rather than the laws themselves, are my primary concern. ${ }^{16}$

Parvin Paidar's work strongly establishes the centrality of women's position within the political discourses of twentieth-century Iran, but there is little explanation of how the Pahlavi state came to include women's rights in its modernization agenda. We are simply told that "the discourse of modernity aimed to bring the familial and social position of women in line with the image of a great-civilization-in-themaking." ${ }^{17}$ Regarding the right to vote, Paidar states that female suffrage was granted "by the arbitrary action of an autocratic ruler." ${ }^{\prime 18}$ We are left with the impression that Muhammad Reza Pahlavi woke up one morning in a good mood and decided to allow women to vote.

Paidar allots only eleven out of nearly four hundred pages to discussion of the shah's gender rhetoric, the WOI, and the family laws passed in the 1960 and 1970 . To the WOI itself, she devotes two paragraphs, with a few further mentions in relation to laws or interchangeably with the state. By 1966 officially recognized women's organizations were structurally linked to the Pahlavi state through the WOI, ${ }^{19}$ but this fact should not constitute a wholesale dismissal of all of its activities. Paidar's definition of the state is confusing, vacillating between laws, the shah's rhetoric, and the actions of individual institutions without distinction (149-6o).

The family laws of the 1960 and 1970 s were the flagship of the state's modernization policy. Despite the state's pretense that these laws were aimed at liberating women and revolutionizing their position, there were other motives behind them, such as population control, and they had a much more limited aim than was pretended (155).

There is no examination of the process by which these laws were conceived, formulated, or negotiated through the state apparatus, nor is there any distinction among the different actors involved within the state. Paidar mentions a newspaper article critiquing the Majlis's (parliament's) failure to reform family laws. She then jumps several years to when the New Iran Party
15. Afary, "Steering between Scylla and Charybdis," 36.

16. See F. R. C. Bagley, "The Iranian Family Protection Law of 1967: A Milestone in the Advance of Women's Rights," in Iran and Islam: In Memory of the Late Vladimir Minorsky, ed. C. E. Bosworth (Edinburgh: University of Edinburgh Press, 1971), 47-64; Behnaz Pakizegi, "Legal and Social Positions of Iranian Women," Women in the Muslim World, ed. Lois Beck and Nikki Keddie (Cambridge, MA: Harvard University Press, 1978), 216-26; Sanasarian, Women's Rights Movement in Iran, 94-97; Gholam-Reza Vatandoust, "The Status of Iranian Women during the Pahlavi Regime," Women and the Family in Iran, ed. Asghar Fathi (Leiden: Brill, 1985), 114-21.

17. Parvin Paidar, Women and the Political Process in Twentieth-Century Iran (Cambridge: Cambridge University Press, 1995), 356.
18. Ibid., 146.

19. Anthony Parsons calls the WOI and similar organizations "quasi-independent para-statal organizations," since they were linked to the state by some member of the royal family, and government ministers often held positions on the planning committees (Anthony Parsons, The Pride and Fall: Iran 1974-1979 [London: Cape, 1984], 28). 
presented a bill to the Majlis that was passed into law. All we are told is that "the bill was codrafted by the WOI and became known as the Family Protection Law." The agency of activists working within the Majlis is erased and transferred to their political party, and we are left with the impression that the role of the WOI was akin to that of a secretary (153).

Paidar describes the WOI as a "closed, hierarchical, and non-democratic institution" that "suffered from decay and corruption inherent in such institutions." While "such institutions" is never explicitly defined, we are left to deduce that she is referring to government institutions, since she qualifies her assessment with an equally vague assertion that "the WOI played an important role in promoting positive policies on women within the state machinery." 20 This last statement is the extent to which the topic is treated. The cursory attention afforded to the WOI allows neither for the agency of activists within the organization nor for the possibility of resistance to the state from within the organization.

Eliz Sanasarian calls the period 1953-66 one of centralization and co-optation of the women's movement by the state, which sought to bring women's independent activities under control. There is no room in Sanasarian's analysis to question the level of this control. ${ }^{21}$ Although she mentions activists' efforts to lobby for legal changes in family laws, she is deeply critical of the fact that they "could only act in accordance with the government to bring about legal changes in women's rights" (89-9o). This lack of institutional autonomy is reason enough to dismiss the agency of activists and the need for a closer look at their process of negotiation with the state. We are merely told that the WOI "did not make demands that could or would not be met; their activities were quite compatible with the government's stand" (79). She dismisses the WOI as a social movement because of this perceived accommodation and subsequent $2 \geqslant 1$ limitations imposed on its priorities and goals.

In Afary's analysis, the first we hear of a women's organization is the formation of the WOI. "In 1966 Muhammad Reza Shah approved the formation of the Women's Organization of Iran (WOI), a new umbrella organization whose president was the Shah's ambitious twin sister Princess Ashraf." ${ }^{22}$ We are given the impression that the creation of the WOI was the shah's idea and that Ashraf Pahlavi jumped at the chance to head this wholly new institution. There are serious problems with this explanation, not the least of which is that a whole history of feminist activism and organization is omitted along with the effects of that activity on the structure and direction of the WOI.

Although the post-1953 period resulted in the consolidation of the shah's political power through repression of various political parties and independent organizations, Guity Nashat argues that "it did not destroy the aspiration of many women who had been active in or had supported the campaign for women's rights."23 Nashat's article is important because it acknowledges the role that activism played in the state's passage of laws. While the right to vote would not have become law without the support of the shah, we cannot overlook that "the ceaseless campaign of many of the older women and younger recruits-hundreds of women professionals, teachers, and students-was instrumental in having suffrage for women included as one of the six points of the White Revolution." Not only does Nashat acknowledge the work of activists for women's rights, she also poses a challenge to the notion that all women's rights were bestowed from above, directly from the hand of the shah: "Later, the regime of the shah tried to claim all the credit for the extension of the right to vote to women." ${ }^{24}$ Nashat's argument recognizes the lack of many political freedoms, but her notion of activism is not dependent on institutional autonomy.
20. To her credit, Paidar does try to acknowledge a difference between the shah and the activists within the WOI, but this statement does not restore any agency to activists, and she does not explore the notion any further, leaving us with the impression of helpless activists, penned within the shah's policies (Paidar, Women and the Political Process, 150).
21. Sanasarian, Women's Rights Movement in Iran, 81-82.

22. Afary, "Steering between Scylla and Charybdis," 38 .
23. Guity Nashat, "Women in Pre-Revolutionary Iran: A Historical Overview," in Nashat, Women and Revolution in Iran, 29.

24. Ibid., 30. 


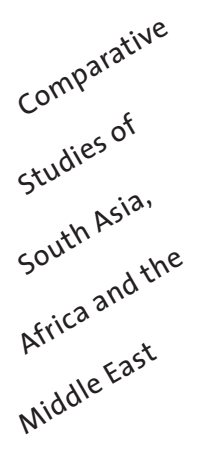

When institutional autonomy is not possible, can we say that feminist activism disappears? As Geraldine Heng points out, "ThirdWorld feminism, by virtue of its vexed historical origins and complicated negotiations with contemporary state apparatuses, is necessarily a chimerical, hydra-headed creature, surviving in a plethora of lives and guises." ${ }^{25}$ Although Sanasarian asserts that many social movements "change form, adapting to varying sociopolitical conditions," she is unable to view state institutional control as one of these conditions. ${ }^{26}$ Unfortunately (though with several notable exceptions), many scholars uncritically draw on Sanasarian's work and demonstrate similar analytic tendencies, attesting to how the erasure of activists' agency within state structures continues to be reproduced.

\section{An Alternate Way to Frame Women's Rights Activism}

According to Sanasarian, centralization of women's organizations during the reign of Muhammad Reza Pahlavi began in 1956, when the minister of labor encouraged a mass meeting of women planned by the heads of several different women's groups. The outcome of this meeting was the formation of the Federation of Women's Organizations (the Federation) in 1959, which consisted of fourteen organizations. Sanasarian places Ashraf Pahlavi's direct control of this organization in 1961, when the Federation became the High Council consisting of eighteen women's associations. Sanasarian contends that "except for following the formalities of building a bureaucratic type organization, the High Council did not do anything else" (8o-81). Viewed through Sanasarian's historical narrative, women's rights groups were passively absorbed into an aggressive state whose main intention was to restrict the demands of civil organizations. Activists within these organizations are assigned a total lack of agency, both in the process of institutional centralization and in terms of their work within these organizations.
Although the class composition of earlier women's organizations was predominantly urban upper- and middle-class, Sanasarian admires their work. She concludes that activists' lack of personal qualities such as "imagination, courage and egalitarian idealism" in comparison to their counterparts in the 1920s, as well as their "subservience to the state ... made them concentrate on purely legal changes for women" $(81)$. This supposed sole focus on legal changes, which benefited only their classes, seems to be the main justification for dismissal of activists in the 1960 s and 1970s. Sanasarian attributes differences in activism to the lack of personal qualities. This view implies that the opposition of earlier feminists vis-à-vis the state reflects these qualities, while a position of cooperation and activism from within the state does not. And it is by virtue of this difference that latter-day activists treated lower-class women, who were not represented in their organizations, as "mere objects of charity" (81). Although Sanasarian does not explain this distinction any further, it is a crucial one that I take up later.

An alternate way to understand the difference between activists who occupy different points in history is to treat them as subjects actively engaged with their respective times. As Joan Scott puts it, "The creation of women as subjects of history places them temporally in the context of their action, and explains the possibilities for such action in terms of those contexts." 27 This point is crucial to keep in mind when examining the metamorphosis of women's organizations alongside their ideological negotiations with the state. Mrinalini Sinha asks the critical question, "Do the ideological constructs that condition women's participation predetermine the nature of women's responses and make any interrogation of the consciousness and agency of women themselves irrelevant?"28 We can learn more about the nature of these ideological constructs themselves and the terms of institutional participation that are negotiated within them. I examine the narratives of activists involved with these
25. Heng, "Great Way to Fly," 30.

26. Sanasarian, Women's Rights Movement in Iran, 1.
27. Joan Wallach Scott, "Introduction: Feminism and History," in Feminism and History, ed. Joan Wallach Scott (Oxford: Oxford University Press, 1996), 4.
28. Mrinalini Sinha, "Gender in the Critiques of Colonialism and Nationalism: Locating the Indian Woman," in Scott, Feminism and History, 483. 
organizations, as well as the context that their activities shaped and that shaped their activities. I take up these narratives as fragments, not as historical evidence per se but "as the articulation of another subject position arising from a certain experience." ${ }^{29}$

This may seem an overly optimistic pursuit, and as Partha Chatterjee has pointed out, we must not underestimate "the powers of a hegemonizing nationalism to take in its stride a whole range of dissenting voices." ${ }^{30}$ The ideological dissonance resulting from activists' negotiations with the state's discourse of nationalism indicates that, rather than a hegemonizing nationalism, it is a dominant nationalism. This difference allows for more distinct existences of other discourses and places the dominant discourse in a position more vulnerable to change. For the dominant discourse to absorb dissenting voices, it must make adjustments to accommodate that absorption, adjustments that ultimately affect its nature. These adjustments, while enabling domination, also provide the possibility of a discursive grammar of resistance. Chatterjee suggests a way to think about this relation between a dominant discourse absorbing critique and the subsequent mutual transformation that takes place:

We cannot find a historically nuanced answer to this question unless we think of the field of discourses as one of contention, peopled by several subjects, several consciousnesses. We must think of discourse as situated within fields of power, not only constituting that field, but also constituted by it. Dominance here cannot exhaust the claims to subjectivity, for even the dominated must always retain an aspect of autonomy. Otherwise, power would cease to be a relation; it would no longer be constituted by struggle..$^{31}$

Dominance is not a position independent of power relations. The state's discourse of mod- ernization provided limits and restrictions through which the women's rights discourse had to voice its demands. The ideological and structural domination that the Pahlavi state exerted over women's rights discourse created a relationship that ultimately enabled subtle changes in the state's discourse of modernization.

Activists' demands, however, compromised their terms and nature, and, maybe because of their accommodating language, forced the state to address and enact laws that it perhaps would not have without this pressure. The state is obliged to accommodate demands in some way, since the state defines and is beholden to its own method of control. Although the state has set up the system of control, it too operates, is restricted, and defined by that same ordering principle of control. Furthermore, it is through this relationship and its restrictions that we can read other relations of restriction, created through domination, which surrounded and gave shape to the Pahlavi state.

\section{Reflections on the Institutional Evolution of Women's Organizations}

The New Path Society (Jama'at-i Rah-i Naw) was an independent organization founded in 1954 that eventually became part of the High Council and then the WOI. Mehrangiz Dolatshahi and a group of her coworkers at the National Development Agency founded the New Path. ${ }^{32}$ Its membership "was of all types," including a variety of women belonging to other occupationally-and religiously-defined organizations, as well as some men. "It was more broad based [than other organizations] and more specifically, its primary goal was women's rights." 33 While we can safely say that the New Path Society was not a national mass movement, it seems to have been a fairly important
29. Gyanendra Pandey, "In Defense of the Fragment: Writing about Hindu-Muslim Riots in India Today," Representations 37 (1992): 47.

30. Although Chatterjee is discussing a hegemonic discourse, I find many of his examples also apply to dominant discourses (Partha Chatterjee, The $\mathrm{Na}$ tion and Its Fragments: Colonial and Postcolonial Histories [Princeton, NJ: Princeton University Press, 1993], 151).

31. Ibid., 137
32. The National Development Agency was created under the joint auspices of the Iranian government and the American-sponsored Point Four program. Dolatshahi describes how the Point Four program helped make educated upper- and middle-class women's employment in offices more acceptable (Mehrangiz Dolatshahi, interview by Shahrokh Meskoob, 15 May 1984, Paris, tape 3, pages 15-16, Iranian Oral History Collection, Harvard University; translations mine).

33. Dolatshahi, tape 3, 17 . 


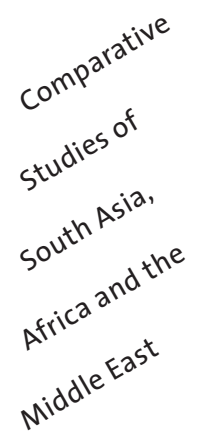

organization among affluent women in Tehran. Although engaged in social work, the main focus of the organization was the political rights of women.

Dolatshahi provides two reasons in hindsight why an organization primarily concerned with women's rights became involved in social work: "Because our society had need for it and because the ladies in the organization needed to keep busy and have activities to engage in." According to Dolatshahi, the significance of these activities was twofold: "One was so that these women could gain some confidence in themselves and recognize that they can do things. Women had been in their homes for so long and they think they are only [suited] for housework and at first they don't have the nerve for activity outside of the house. And the other reason is for society to see that these ladies can be effective and get things done."34 Put another way, middle-class activists empowered themselves by providing social services for lower-class women so that they could then approach male officials within the state to push for legal changes. The acquisition of political standing through social work is a relation with enormous class implications, which I take up later.

The New Path's primary point of emphasis was family law, above the right to vote, because if we have the right to vote, many will not pay attention [tavajjuh] to it. And women don't vote and if they do they cast a vote but don't really participate the way that they should. But if family laws are fixed any person, whether they are aware or unaware [of family law] is included and will utilize it [family law]. ${ }^{35}$

This statement challenges the claim that the primary goal of feminist activism during the $195^{\circ}$ and early 1960 s was to gain the right to vote. The justification provided for this prioritization of family laws above suffrage demonstrates a lack of faith in women's political awareness or ability to "correctly" participate politically. Reform of family laws is deemed more "useful," since marriage is considered the reality of all women and does not require the modern consciousness necessary to claim this right. The focus on family laws is an attempt to push for change on an issue that will improve women's rights, since a woman does not have to be aware of the right to benefit from it. What is hinted at is the passivity of some women, which is in marked contrast to the subject position from which Dolatshahi herself speaks. This is a relation of service based on difference, of active women defining and representing the interests of the majority, based on a perception of this majority as passive beings.

Within the New Path, the representative structure was one of inclusive decision making and democratic participation. While different commissions reported once a week to the board of directors, monthly meetings were held to give all members the opportunity to hear the progress of various commissions, to express opinions and suggestions, and to get new information regarding rights. The composition of commissions was based on voluntary participation. ${ }^{36}$ A number of these meetings focused on understanding and discussing the constitution (qanun-i asasi) or the civil code (qanun$i$ madan- $i)$, especially pertaining to the family, women, and children. The New Path's strategy was to raise the awareness of educated women of the upper classes about existing rights and to engage in debates about how these rights needed to be changed. Powerful government officials, judges, and lawyers were invited to these debates. ${ }^{37}$ Dolatshahi states that they "did not exaggerate, we didn't try to instigate people to rise up and yell." Their strategy was not a radical one of violence or agitation, it was a more cooperative approach toward enacting change; they chose to raise awareness and create forums for discussion: "We would say that these men that we now live with did not create these circumstances. This state of affairs is centuries old. But we must, through discussion and negotiation and debate, try to convince these men and to make them aware of how bad these laws are until they are fixed." 38 
This is a conciliatory and nonconfrontational approach, which espouses changing laws through discussion and raising awareness. While this approach may seem far from radical, and consciously supportive of the state, it is nevertheless lobbying for change from within the system. ${ }^{39}$ Pro-establishment does not mean prostatus quo in terms of the laws of that establishment. Therefore, while Dolatshahi cooperated with the state in terms of working through it, she resisted the status quo and attempted to enact change through legal means. While there are drawbacks to this approach, this does not constitute a lack of activism.

The first sign of centralization of women's organizations comes with the establishment of the Federation of Women's Organizations. Dolatshahi recalls that the activists in various organizations decided to organize themselves. "Because naturally it was necessary for the different women's societies to cooperate with each other and for each group not to just go their own way. As a result, in $195^{6}$, about a year after the New Path Society was established, a number of women's societies gathered together. First we were 14 societies and we began to think about creating a cooperative organization, a federation out of the different societies." 40 Part of acknowledging the agency of women's rights activists is to recognize their participation and agency in creating their institutional relation to the state. The nature of this cooperation was one of coordination of activities and resources according to the orientation of each organization. For instance, some organizations engaged only in social and charity work and did not lobby for political rights. Others, like the New Path, engaged in both types of work and coordinated social-work activities with organizations that did not engage in political activities. The different organizations each sent one representative to the Federation to act as a liaison be- tween their organization and the Federation's 235 elected board of directors. ${ }^{41}$

One society belonging to the Federation, the Seventeenth of Day Society, ${ }^{42}$ asked Ashraf Pahlavi to be their honorary president (ra'is$i$ 'ali). Dolatshahi describes this society as one that "was not very serious." Pahlavi's acceptance of the position sparked debates on autonomy and organization within the Federation. "We discussed whether or not this act was right because this act had good and bad aspects. The majority were of the opinion that we needed to stand on our own feet and if individuals from the royal family wanted to recognize us, they could help us or we could ask them for help, but as a rule, the Federation of Women's Organizations had not asked anyone to be the president." 43

Institutional autonomy was a hotly contested issue. Although it was a means of independence from government control, that control could provide women's organizations with funding, as well as official support for their projects. ${ }^{44}$ Uproar among the women's organizations caused individual activists to take the matter to the state. According to Dolatshahi, the shah had decided that if his sister was to head one organization in the Federation, she should head all of them, supposedly to avoid charges of favoritism. Dolatshahi attributes the shah's desire for control over women's organizations to the fear that they would be appropriated by dangerous leftist movements. ${ }^{45}$ Activists within the different organizations weighed their options and decided to accept Ashraf Pahlavi's leadership. The choice was a consciously pragmatic one, where a degree of control was exchanged for the promise of increased effectivity in their work. But the continually fluctuating degree of control was to result in a relationship, both institutionally and ideologically, that warrants attention.
39. Although such an approach may not seem radical from a present-day feminist perspective, by her own account Dolatshahi was viewed as a radical by her well-educated uncle, who was a judge (Dolatshahi, tape 3,19$)$.

40. Mehrangiz Dolatshahi, interview by Shahrokh Meskoob, 15 May 1984, Paris, tape no. 4, Iranian Oral History Collection, Harvard University, 13.
41. Dolatshahi, tape 4, 14.

42. Day is an Iranian month roughly corresponding to 22 December-19 January. The Seventeenth of Day is the date that Reza Shah ordered women to unveil. Later, it became a day of celebration for various women's organizations.

43. Dolatshahi, tape 4, 15.
44. "Now this is a problematic aspect and one that I think the Federation got to thinking that should they put Princess Ashraf, who was a smart and capable person, as the head of the women's organizations on one hand she could help and on the other hand she could have [the organizations] under her control" (Dolatshahi, tape 4, 15).

45. Dolatshahi, tape 4, 15-16. 


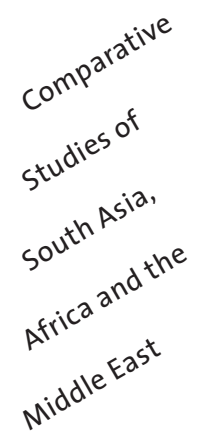

The new institution created under the honorary presidency of Ashraf Pahlavi and with the active participation of the Federation was the High Council. The organization's activities were more centralized and subject to Pahlavi's control, but the High Council's domestic activities were not significantly different from the Federation's. This was not the case on the international front. "One of the orders that the shah gave to Princess Ashraf was to control the organization's international activities so that just anyone would not be permitted to go to any conference." Dolatshahi describes how before the High Council, any persons involved with these organizations with enough money to pay their way could go to international women's conferences, regardless of their qualifications. After the High Council was established, it sent and paid for the most qualified representatives to attend international conferences, a change Dolatshahi considered a positive aspect of state control. ${ }^{46}$

The High Council's participation in internationally sponsored activities was sometimes used as a leverage point against the state. At times when the state did not choose to send High Council activists to international events, the positions of activists within these international organizations could be used to gain representation despite this exclusion. "Without the support of Princess Ashraf and the High Council in sending me to all of the meetings of the International Council of Women, I would never have reached a level in the International Council to become elected its leader." ${ }^{47}$ It would have been profoundly embarrassing for the state had it curtailed Dolatshahi's attendance from the International Council's events. This prestige and prominence on the international scene also enhanced activists' positions vis-à-vis the state. Dolatshahi recalls the importance of the International Council's support of a draft of reformed family laws in consolidating the High Council's support of this draft. The High Council then took this draft to the ministry of justice, since there was no Majlis in session at the time. While nothing immediately came of the proposal, Dolatshahi describes this sort of access to state institutions as novel; the draft became the basis of what was eventually passed by later activism within the Majlis. ${ }^{48}$ It was not until some activists were elected to the Majlis that reform of family laws was passed, yet the High Council's new state affiliation afforded activists greater representation on the political scene, domestically and internationally, even as it subjected their activities to institutional control.

Although the High Council facilitated a more unified, organized, and controlled presence within the state, as well as international institutions, individual women's organizations still continued their various social, charitable, and political activities at the local level. These activities were subject to supervision and coordination, but the existence of the High Council did not alter the structure of these organizations, and, in many cases, it aided their activities through increased cooperation with each other and with relevant state organs. Dolatshahi ascribes these beneficial aspects of the High Council to the power and support that Ashraf Pahlavi garnered. It was at the encouragement of experienced activists that Ashraf Pahlavi began to participate directly in international conferences. According to Dolatshahi, while Pahlavi had decision-making power over institutional matters and was a major liaison with the state, the years of experience that leading activists had in running these organizations were the basis for both domestic and international activities. ${ }^{49}$ In other words, activists did not become clones of Pahlavi. Rather, their cooperation and compromise with her allowed them to bring their own agendas to the table to create an institution that was the result of an active exchange of skills and experience, albeit from a subordinate position of power.

Increased participation of international activities brought activists into contact with other women's rights activists from all over the
46. Dolatshahi, tape 4, 16 .

47. Dolatshahi, tape 4,17

48. Dolatshahi, tape 4, 17. See Dolatshahi, tape 7, 6-13, for an account of how activists worked through the Majlis to pass the Family Protection Law.
49. Dolatshahi describes how Pahlavi actively included Dolatshahi, who had years of experience in the international arena, in planning the High Council's involvement with international activities. Dolatshahi and other activists encouraged Pahlavi's direct participation in these activities. This participation seemed limited to attending and speaking at the opening of a conference. Aside from this, activists were left to participate according to their own judgment (Dolatshahi, tape 4, 17-19). 
world. Dolatshahi conveys a sense of certain norms and ideals that circulated within this international forum, which became institutional and policy goals for domestic organizations. One ideal was that of mass participation, denoted by increased membership in women's organizations. Dolatshahi describes this goal as one of the primary reasons behind the creation of the Women's Organization of Iran in 1966, a more centralized institution, which was to coordinate increased membership and activities through its virtual monopoly on women's rights activism in Iran. ${ }^{50}$ Activists discussed the matter with Ashraf Pahlavi, advising caution and patience for the growth of civil institutions and mass participation from below, rather than institutional cannibalism from above. They argued that increased membership would result from increased education, employment, and political participation, rather than from institutional changes that would swallow the membership of other organizations. ${ }^{51}$ Although the WOI served the state's political and social agenda more than that of women's rights activists, activists engaged with this institutional shift and were conscious of its dangers.

Ashraf Pahlavi wanted to create a unified, nationwide women's organization to replace all other women's organizations to gain mass participation (or the semblance of mass participation for international eyes) and increase institutional centralization (which she envisioned as increased effectiveness). Paradoxically, the same international ideals that inspired Pahlavi's idea of a national organization also constrained the resulting form of the institution. If the WOI replaced all other women's organizations, it would forfeit its membership with the International Council of Women, "because the terms of membership of the International Council are that member organizations act as an umbrella to aid and coordinate different organizations, in different fields, nation wide." ${ }^{22}$ This stricture was meant to encourage the growth of civil society along a democratic trajectory, rather than to aid the consolidation of civil organizations un- der an autocratic state. As a result, the WOI re-

placed individual societies in the provinces with WOI branches but allowed organizations operating in the capital to continue their activities under the supervision of the WOI. ${ }^{53}$ As Dolatshahi notes, the WOI was no longer a federated body constituted by and run by individual member organizations; now “this women's organization was the rival of other women's societies, but it had greater political and financial power." ${ }^{44}$ Even while activists opted to continue working for women's rights in an environment of ever narrowing institutional options, they were aware and critical of the drawbacks of these institutional changes.

Although international considerations had salvaged the existence of individual women's organizations in Tehran, they were subject to the supervision of a branch of the WOI called Women's Organization of the Capital (Sazman-i Zanan-i Pay-i Takt). Dolatshahi is critical of this new chain of command, especially because the head of the supervising WOI branch "was not in favor of the existence of the societies." Since the head of these societies, who acted as their liaison with the WOI, thought them to be superfluous and unnecessary, the organizations were further isolated and constricted in their activities. ${ }^{55}$ Dolatshahi also critiques the domestic activities of the WOI, which had grand plans to provide services and classes, organize conferences, and open many branches with its sizeable budget and considerable resources.

But, in my opinion, these projects did not have the depth that they should have. Sometimes, and this was not something unique to the WOI, it happened everywhere, some activities were for show [namaayish-i]. For example, they would have a seminar in some far flung province on women with a lot of work and coming and going and the Princess going and afterwards you would hear nothing about it and not know if the seminar had yielded any results. ${ }^{56}$

Dolatshahi perceives a general level of ineffectiveness in the WOI's activities and its
50. Dolatshahi relates that Pahlavi's visit to Poland's women's organization, which claimed a membership of three million, made an impression on Pahlavi by virtue of her and the shah's "enthusiasm for everything to be big and grand" (Dolatshahi, tape 4, 21-22).
51. Dolatshahi, tape 4, 22.

52. Dolatshahi, tape 4, 23.

53. Dolatshahi, tape 4, 23
54. Dolatshahi, tape 4, 25.

55. Dolatshahi, tape 4, 25-26.

56. Dolatshahi, tape 4, 26. 


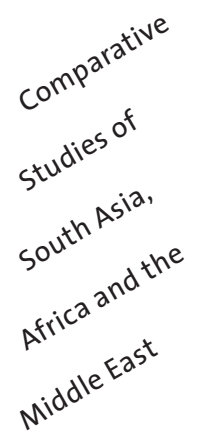

hampering of individual organizations, one of which was the New Path. On the international front she admits that the WOI did relatively well in sending the same representatives to UN conferences, although the WOI "were not organized enough" with other international organizations. They sent different representatives each time, hampering the WOI's effectiveness by failing to send experienced representatives or by preventing new representatives from gaining experience. These criticisms are in marked contrast to her appraisal of the High Council's perceived level of effectiveness. State affiliation was beneficial so long as it did not severely stifle or replace individual organizations. But the degree of centralization and control achieved by the WOI's relation to the state is perceived as counterproductive. ${ }^{57}$

\section{Unequating Ashraf Pahlavi with the Shah and the State}

Ashraf Pahlavi's position needs to be problematized, since it is primarily according to perceptions of her power over women's organizations that most researchers dismiss or laud an organization. Many activists of the period working within state-affiliated organizations defended the integrity of these organizations by describing her role as cursory. Pahlavi is portrayed as a figurehead, useful because she is able to lobby the shah and to gain access to different facets of the state on the organization's behalf. ${ }^{58}$ Those scholars who dismiss the WOI as a pawn of the state view Pahlavi's role as significant, as the link through which the state (and more specifically the shah) controlled the organization. ${ }^{59}$

However, it would be a mistake to understand Ashraf Pahlavi as the female version of the shah. Far from being the shah's pawn, she was, as Marvin Zonis describes her, "a formidable player in Iranian politics." ${ }^{\circ 0}$ Although Pahlavi had a vested interest in the continuance of the current regime, she sought both to support her brother as well as to influence him according to her own interests. ${ }^{61}$ The different accounts of Pahlavi's involvement and level of control reflect the ideological variations of activists working through state-affiliated institutions. Pahlavi, in her own memoir, discredits prior women's movements and activism, locating the real burst of women's activism with her own entry into the effort: "At the time I began my work for women's rights, we had a few scattered women's organizations, working at random, without any long-range goals or purpose." ${ }^{62}$ According to Pahlavi, most of these women's groups did voluntary charity work rather than engage with any political or economic issues. A radically different picture of the situation comes from Mahnaz Afkhami, who served as the secretarygeneral of the WOI from 1970 to 1979 and as minister of women's affairs from 1975 to 1979; Afkhami recognizes the agency of other activists, including herself. ${ }^{63}$ Afkhami's description of Pahlavi as a figurehead is in marked contrast to Pahlavi's own description of her role as instrumental in creating the High Council, and later the WOI: "I met with representatives of various organizations to create a framework for our women's movement." ${ }^{64}$ With this statement, Pahlavi not only places herself in a more central and active role than that of simply providing the meeting space but also dubs that meeting as the beginning of the women's movement. This is an erasure of women's activism before affiliation with the state. Afkhami, on the other hand, sees this particular meeting more as a change in the form of the existing women's movement, and she does not participate in the same erasure of prior women's activism.
57. In a similar vein, Ozma Adl criticizes the professionalization of activists and what she perceives as undue focus on legal changes (Ozma Adl [Naficy], interview by Habib Ladjevardi, 10 February 1984, Cambridge, tape 1, Iranian Oral History Collection, Harvard University, 19-20).

58. For instance, see Mahnaz Afkhami, "Iran: A Future in the Past-The 'Prerevolutionary' Women's Movement," in Sisterhood Is Global: The International Women's Movement Anthology, ed. Robin Morgan (Garden City, NY: Anchor, 1984), 331-33.
59. For instance, Sanasarian points to Ashraf Pahlavi's power to appoint the majority of the WOl's Central Council. For a more detailed discussion of the WOI's organizational structure, see Sanasarian, Women's Rights Movement in Iran, 83-85.

6o. Marvin Zonis, Majestic Failure: The Fall of the Shah (Chicago: University of Chicago Press, 1991), 122.
61. Ibid., 126. For a description of Ashraf Pahlavi's close relationship with her brother and of her own autonomous power, see also Adl, tape 2, 9-10.

62. Pahlavi, Faces in a Mirror, 154.

63. Afkhami, "Iran: A Future in the Past," 337.

64. Pahlavi, Faces in a Mirror, 154. 
While this difference could easily be attributed to Afkhami's more autonomous position writing after the Anti-Shah Revolution, her description of the evolution of women's organizations and strategies reduces the importance of Pahlavi's actual role and refocuses it on how activists reconciled and implemented a compromise with the state and its modernization policies. This approach shows the debate around this transformation, from which we can locate activists' participation in this process of institutional transformation. The nature of this active deliberation and decision making is crucial to understanding the way activists worked within the state and the resulting impact on women's rights, particularly for women of different classes. Women's rights activists who adopted the nationalist construction of gendered modernization "became active agents in the nationalist project-complicit in the framing of its hegemonic strategies as much as they were resistant to them because of their subordination under the new form of patriarchy." 65

\section{The Modernization Bandwagon}

Afkhami admits that the Pahlavi state, "although by no means feminist in orientation, at least was committed to modernization and change." ${ }^{66}$ For Afkhami, the necessity of cooperation and compromise with an autocratic state is a given. This commitment to modernization and change is the lowest common denominator between the state and women's rights activism, making cooperation possible. If the state could include women's rights as part of its modernization projects, women's rights could be framed to make this incorporation possible. Compromise is represented as a matter of practicality, a way of procuring results. Thus, to garner state support for women's increased economic participation, activism positioned women as central to the nation's economic development. According to Afkhami, "Education in the broadest sense is the most important vehicle to bring about change," and "economic independence is one of the first priorities and the basis for achievement of other rights" (331). We see how, theoretically at least, the feminist objectives of 239 women's economic independence and higher levels of education are presented in such a way so as to appear harmonious with and integral to the state's development objective of an expanded and more skilled labor force. "Thus, special programs to combat illiteracy among rural women were not demanded solely on the basis of women's right to education, but as a necessary means of modernization" (332). The question remains, though, which aspects of women's rights were compromised by framing their increased economic participation in nationalist terms?

Although Afkhami and Dolatshahi both mention the necessity of political power for activists to gain rights for women, there is little mention of political participation of any kind for the class of women that activists have taken it upon themselves to represent. Article 1 of the WOI's constitution states that "the ultimate purpose and the mission of the Women's Organization of Iran is to raise the cultural, social, and economic knowledge of the women of Iran and to make them aware of their family, social, and economic rights, duties and responsibilities." 67 There is no mention of political awareness or participation as a goal for Iranian women in general, in contrast to the necessity of these qualities for women's rights activists themselves. Furthermore, women's rights are contingent on duties and responsibilities. This presents a trade-off: women's rights are exchanged for the responsibilities of modern citizenship and the duty of participation in a capitalist economy.

\section{Speaking from Within: \\ Women's Rights and Modernization}

Institutional control meant that activists had to work within the ideological constraints of the state's nationalist modernization policy. An activist narrative written during the reign of the last shah provides a better understanding of what this compromise meant. The autonomy enjoyed by both Afkhami and Dolatshahi in their narratives is not present in this account of the women's rights movement by long-time
65. Chatterjee, Nation and Its Fragments, 148. 66. Afkhami, “Iran: A Future in the Past," 331.
67. Women's Organization of Iran, The Constitution of the Women's Organization of Iran (Iran: The Organization, 1975), 3 . 


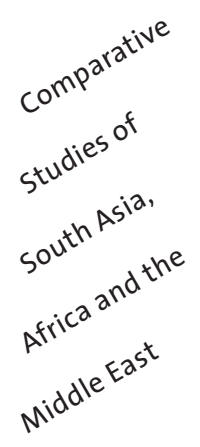

activist Badr ol-Moluk Bamdad. While it is easy to read Bamdad's narrative as sycophantic, the nuances of her narrative provide a glimpse of the implications of the ideological compromises that constitute her discourse of women's rights. ${ }^{68}$

Bamdad is primarily concerned with impressing on the younger generation the enormous transformation that has taken place in women's status through comparison with her rendition of the past. The point here is not to look for historical accuracy, but rather at the way that Bamdad's narrative constructs a specific picture of women's activism in relation to the state. She begins with an ahistorical, traditional woman whose complete oppression contains few variations according to class or locale. Her narrative describes the Constitutional Revolution as "Women's Awakening" (25-54). Activism, from this time until the 1930s, is seen as dangerous and uphill struggle undertaken by courageous women in a time of darkness (55-9o). While she acknowledges the activism of women before this time, she clearly understands the creation of the state-sponsored Ladies' Center as the beginning of the women's movement. Bamdad expresses a sense of relief at the state's adoption of issues for which activists had been pressing for years. She lauds the increased provisions for women's education, unveiling, and admittance of women into Tehran University as some of Reza Shah's most significant reforms (91-104).

The chapter titled "Troubled Times" discusses setbacks to the cause of women's rights because of a loss of royal patronage: "After September 1941, when the women's movement unexpectedly lost the support of the great royal patron who had done so much for their freedom and happiness, reactionary elements on every side seized the opportunity to start agitating and causing trouble" (106). The state is seen as a bulwark of protection and rationality against ever-looming reactionary forces with the power to instigate mass opposition. This power stems from the "simple-minded and excitable" nature of the masses who are easily led astray by their ignorance and irrationality (1 19). But since women during Reza Shah's reign had "tasted freedom," they resisted the attempts of "agitators" at reversing women's rights. The activities of these enlightened women "had some effect in preventing a setback in the condition of the great mass of women in old-fashioned families" (107). In Bamdad's narrative, too, "enlightened" (i.e., upper-class) women act as the vanguards and protectors of helpless traditional (i.e., lower-class) women.

Bamdad is careful to distinguish between traditional reactionary elements and the religion of Islam. Any opposition to women's rights is traditional and thus reactionary, because of the inherent opposition of tradition in relation to modernity, which comes to stand in for social modernization and economic development in her narrative. But, she argues, reaction is not the same as religion, since "true" Islam is compatible with the enlightened goals of modernity/modernization. Religious opposition is reactionary because it espouses a form of Islam corrupted by tradition: "While adversaries of women's advancement all too often invoke religion in support of their attitudes, scholars who have made profound studies of the subject are convinced that the laws of Islam, if properly understood and enforced, provide the best assurance of the good life and guarantee women's legitimate rights" (lllll). Bamdad thus posits women's rights as intrinsic to Islam, and the past conditions of women and the clerical opposition to women's rights are understood as the result of distorted notions of Islam and a corrupt and backward clergy and society.

But the nationalist agenda of modernization was predicated on modernized patriarchy rather than on gender equality. While Bamdad's feminism is based on the rights of the individual as espoused in the UN Declaration

68. Bamdad's activities were not always in cooperation with the state. While she gladly took advantage of the state's initiative to open Tehran University to women, in later years her newspaper, Today's Women (Zan-i Imruz), was often banned by state authorities (Bamdad, From Darkness into Light, 106; and Dolatshahi, tape 3,6). 
of Human Rights, expressed in the nationalist context, rights are contingent on the selfless fulfillment of duties and responsibilities to the nation $(124-25)$. Ideally, in the nationalist context, an educated woman uses her emancipation to serve and obey nationalist prerogatives, which are designed for the good of the greater community. ${ }^{69}$ Bamdad repeatedly emphasizes the need for education and modernization for the benefit of the nation, not because women are important as individuals but because it makes them better wives and mothers. ${ }^{70}$ This compromise and contingency of rights reflects a version of modernity still firmly ensconced in patriarchal relations. If the primary reason women should be given rights is for them to be better wives and mothers, a woman's position is largely determined by her relation to men. Therefore individual rights are being sought, but they are procured through compromise with and subordination to the duties of a patriarchal nationalist discourse, which allows for the appropriation of women's rights into the practices of domination.

Women gain their very subjecthood according to their perceived level of modernization according to the nationalist ideal. Bamdad describes women's legal right to vote and run for office as "the proclamation of the equality of men's and women's rights." Aside from the fact that this political right was not accompanied by attendant social and economic rights, the majority of women were not "modern" enough to claim this right of citizenship, since "the majority of the nation's women had been trammeled by their upbringing with outworn ideas and notions." What was now needed was a complete transformation of behavior and thought, from a traditional trajectory to a modern one: "Now it was necessary to inform them [women] of their rights which they had acquired and of the duties

which would henceforth fall on them, and generally to prepare them for enjoyment of freedom and recognition of its limits."71 An understanding of freedom is contingent on a grasp of its limits. According to Bamdad, it is the job of the activists who had fought for these rights to inculcate their meaning and attendant responsibilities in the population that they supposedly represented. ${ }^{72}$

Not only does Bamdad's concept of rights and duties establish a problematic power relation, it also implies a different set of rights for women according to the degree of their modernization, which fell largely across class lines. As Partha Chatterjee has commented, "The story of nationalist emancipation is necessarily a story of betrayal. Because it could confer freedom only by imposing at the same time a whole new set of controls, it could define a cultural identity for the nation only by excluding many from its fold; and it could grant the dignity of citizenship to some only because the others always needed to be represented and could not be allowed to speak for themselves."73 The emancipation of women in Iran was the emancipation of a select group of women, along class lines; it was an emancipation gained according to a distinction from and at the expense of lower-class women. Activists were set in a position of power over lower-class women and charged with the task of "humanizing" them by subjecting their minds and bodies to a process of modernization. This task marginalized the rights and power of lower-class women within state-sponsored women's rights discourse, just as the feminist discourse of gender equality was marginalized through activists' negotiation with the state's modernization discourse.
69. Dipesh Chakrabarty also discusses the nationalist ideal of selflessness in the Indian context, which is relevant to the Iranian case: "This model of the 'modern' Bengali/Indian woman-educated enough to appreciate the modern regulations of the body and the state but yet 'modest' enough to be unselfassertive and unselfish-was tied to debates on 'freedom.' 'Freedom' in the West, several authors argued, meant jathechhachar, to do as one pleased, the right to self-indulgence. In India, it was said, freedom meant freedom from the ego, the capacity to serve and obey voluntarily" ("Postcoloniality and the
Artifice of History: Who Speaks for 'Indian' Pasts?" Representations 37 [1992]: 14).

70. Bamdad, From Darkness into Light, 25, 55-66, $126-$ 27.

71. Ibid., 121.

72. This is an old impulse. According to Afsaneh Najmabadi, from the mid-nineteenth century, the traditional woman was the most prominent symbol of backwardness: "Correspondingly the journey into modernity was defined as one of educating and unveiling this backward subject" ("Hazards of Modernity and Morality: Women, State, and Ideology in Contemporary Iran," in Women, Islam, and the State, ed. Deniz Kandiyoti [Philadelphia: Temple University Press, 1991], 51).

73. Chatterjee, Nation and Its Fragments, 154. 


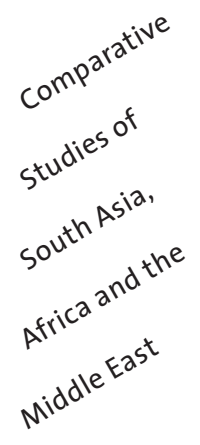

The Price of Cooperation:

Compromising the Rights of Lower-Class Women

Social transformation, from a traditional existence to a modernized one, was a necessary part of activists' projects for women. This contention between the need for unity of identity (we, the women of Iran) and the need to recognize difference within that identity (we, on behalf of the women of Iran) is a discursive paradox of women's rights activism inscribed within a modernizing agenda. This paradox created a specific power relation that indicates how a discourse of gender equality can come to practice a relation of domination.

Mehrangiz Dolatshahi's description of the New Path's activism in southern Tehran provides an example of a lower-class urban context. The organization opened a social services center, which provided a variety of classes for poor, illiterate women, including classes on health and hygiene, child rearing, cooking, sewing, and literacy. These classes were designed to instill "modern, scientific" methods of domesticity, personal hygiene, child rearing, and enough literacy for women to function in a modern society. Dolatshahi describes the nature of these classes and the teaching methods used:

For instance, we would teach them to get their child's birth certificate at the right time, not when they wanted to put the child in school and then they don't have the birth certificate and come to us for help, or to keep their houses clean. We would give these kinds of assistance and offer prizes. For instance, we would teach the women, don't leave your trash in front of the door to your house, clean your house, wash your windows, don't dip your dirty toilet implements [aftabih] in the courtyard pool [hawz] and then when the women would do these things, [the New Path activists] would say, good, because you have learned these things so well now we will give you a prize $[j a y z i h]$, we will buy your child clothes or get something for you. ${ }^{74}$

This narrative implies that women did not know how to cook, clean, or take care of their children before their encounter with the New Path, because their methods were not modern and therefore did not register as methods at all.
From this point of view, tradition is equated with irrationality, disorder, filth, and ignorance and therefore cannot be identified as something systematic. This condescending assumption is reflected in the strategy by which "proper," modern methods were taught. This strategy, the reward system, is one of overt instruction, reminiscent of the unsubtle training children receive. By infantalizing other women, activists assume the role of a mother beholden to the state, a dominating role similar to that of a father.

Lower-class urban women were not included in the New Path's debates over their social service policies; rather, these women were to be acted on. Dolatshahi's description of their needs is telling of how this interpretation shaped the nature of middle-class women's activism toward poor urban women. For middleclass women, charity work prepares them for involvement in civic activities. But for poor women, they are to learn how to keep their houses clean and to cook better so that their husbands will stop beating them. ${ }^{75}$ The nature of activism and the rights women are entitled to in lived experience appear to change with respect to activists' perceived distinctions in women's levels of modernization and their concomitant class positions.

The proceedings of a 1975 WOI-sponsored international conference on functional literacy, "The Design of Educational Programmes for the Social and Economic Promotion of Rural Women,"76 provide a view of women's rights activism in a rural lowerclass context. The shared concept of the contingency of rights and duties, according to perceived degrees of modernization, provided a common ideological grammar that highlights the inherent harmony among the modernization policies of international organizations, the Iranian state, and the WOI. In other words, modernization discourse lent itself to a relation of domination in various contexts, whether as part of an internationalist discourse, a nationalist discourse, or a discourse of gender equality. Activists from different countries formed a community based on their position
74. Dolatshahi, tape 3, 23-24.

75. Dolatshahi, tape 4, 1.
76. The conference was presented in honor of the UNsponsored International Women's Year in 1975. 
as "modern" upper-class women engaged in discussions about how to modernize largely illiterate, rural, lower-class women. The activists' view was that through a specific form of literacy, called functional literacy, these traditional beings would become active citizens in the social and economic life of the modern nation-state. In her opening remarks at the conference, Ashraf Pahlavi states that "the literacy program will transform the submissive and passive into beings of a new type-into beings able to share the sufferings and difficulties of others, who will develop a critical consciousness and know how to pose problems objectively, who will find fulfillment in constructive work and who will, above all, be receptive to others." ${ }^{77}$ Rural women are represented as submissive and passive beings, incapable of rational thought, engaged in meaningless work, with an almost subhuman emotional consciousness. In these discussions of rural lower-class women, feminism constitutes itself along class lines, mirroring international norms of socioeconomic modernization. ${ }^{78}$

Afkhami's conference speech provides an interesting contrast to her article written after the Anti-Shah Revolution. Here we see the limits imposed on her speech by her position within the state. "The issues to be discussed in this seminar are matters which bear upon individual dignity, social justice, and national progress." 79 Her statement distinguishes individual dignity from society and the nation, an acknowledgment entirely absent from Pahlavi's speech. But Afkhami's acknowledgment has limits. Afkhami attempts to present rural women as active participants in their own modernization, to show that this process is voluntary. She states that the project "would succeed only to the degree that we engage the women of Saveh as full partners in a common endeavor" (5). However, the program's actual design shows cooperation as a secondary consideration at best. For instance, out of nineteen issues, rural women in the Saveh district listed

family planning ninth in importance. However, the program spends three out of eighteen weeks on family planning. The WOI justified the amount of time allocated to family planning by pointing to social indicators such as high pregnancy and birth rates, early marriage, and high infant mortality rates (33). The WOI's concentration on family planning reflects state concerns: the state is interested in population control, since pregnant women and women with many children are less likely to be economically active, in the sense of wage labor. According to this reasoning, rural women don't know any better, and the experts overrule their requests. Though Afkhami insists, "In sum, the Project is not something which the Women's Organization has done for, or to, the women of Saveh, but a programme which we have carried through together" (6), statements like this must have rung hollow to the rural women involved in the program.

\section{Conclusion}

This cross section of narratives, of individual experiences and perspectives, is far from representative of all women's rights activists within the state. Instead, it indicates trends that help us find new ways to explore old questions. With this in mind, "without impugning the courage and vision of upper- and middle-class women who were literate and educated ... we can still consider the contradictions their class positions put them in vis-à-vis other women." ${ }^{80}$ Writing a critical history of women's rights activism in an autocratic context is contingent on preserving the agency of upper-class activists. Without this agency, we participate in erasure of history by speaking for activists rather than analyzing their discourse, and thereby reinscribe a relation of dominance. While Lila AbuLughod warns us "not to accept uncritically the terms of the upper- and middle-class women involved in most feminist projects-the notions
77. The Women's Organization of Iran and the International Institute for Adult Literacy Methods, The Design of Educational Programmes for the Social and Economic Promotion of Rural Women: An International Seminar 19-24 April 1975 (Tehran: Women's Organization of Iran, 1975), 3.
78. For an account of how activists found cooperation and commonality at the international level with women of similar ideological and class orientations, see Dolatshahi, tape 4, 19-20.

79. Women's Organization of Iran and International Institute for Adult Literacy Methods, Design of Educational Programmes, 4. 8o. Lila Abu-Lughod, "Feminist Longings and Postcolonial Conditions," in Remaking Women: Feminism and Modernity in the Middle East, ed. Lila AbuLughod (Princeton, NJ: Princeton University Press, 1998), 24. 


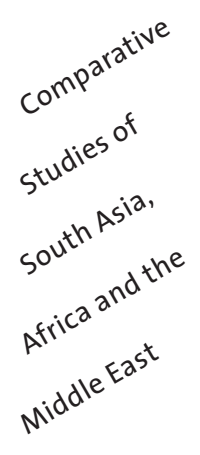

of 'awakening,' 'women's rights,' and 'empowerment' that are part of the narratives of progress and enlightenment," 81 doing exactly that helps us locate paradoxes surrounding these notions within their own words, through their own agency.

The conceptual bind between gender equality in feminist discourse and modernized patriarchy in modernization discourse created an elitist form of women's rights activism in Iran. The induction of activism into the state's modernization framework not only circumscribed the ability of activists to procure rights but also ensconced activists in a paternalizing intragender dominance with respect to lowerclass women. Activists adopted modernization discourse's hierarchies of exclusion and domination, which limited their ability to substantially alter patriarchal relations. According to Teresa de Lauretis, the feminist subject is "not unified or simply divided between positions of masculinity and femininity, but multiply organized across positionalities along several axes and across mutually contradictory discourses and practices." Race, class, nation, and sexuality constitute these other axes, creating the feminist subject as "much less pure, as indeed ideologically complicitous with 'the oppressor." "82

By dehumanizing lower-class women, activists were able to inscribe their reforms within the nationalist agenda of modernization. This complicity haunted them, since it also entailed accepting the limits of modern patriarchy on these reforms. Activists fighting for reform of family laws were trying to reform traditional patriarchal relations, which in turn codified and strengthened the modern patriarchy espoused by the state. As a result, class divides were reproduced and reinforced, and a whole stratum of lower-class women, labeled as traditional, was alienated. Articulations of class, gender, and nation are indeed "relationally implicated in one another," 83 and these relations manifest themselves in power negotiations. At stake in analyzing these negotiations is a concept of agency that informs relations of power as fluid and multiple and that comprises spaces of resistance. $S$ 